\title{
SPATIAL OPTIMIZATION OF SIX CONSERVATION PRACTICES USING SWAT IN TILE-DRAINED AGRICULTURAL WATERSHEDS ${ }^{1}$
}

\author{
Margaret M. Kalcic, Jane Frankenberger, and Indrajeet Chaubey ${ }^{2}$
}

\begin{abstract}
Targeting of agricultural conservation practices to the most effective locations in a watershed can promote wise use of conservation funds to protect surface waters from agricultural nonpoint source pollution. A spatial optimization procedure using the Soil and Water Assessment Tool was used to target six widely used conservation practices, namely no-tillage, cereal rye cover crops (CC), filter strips (FS), grassed waterways $(\mathrm{GW})$, created wetlands, and restored prairie habitats, in two west-central Indiana watersheds. These watersheds were small, fairly flat, extensively agricultural, and heavily subsurface tile-drained. The targeting approach was also used to evaluate the model's representation of conservation practices in cost and water quality improvement, defined as export of total nitrogen, total phosphorus, and sediment from cropped fields. FS, $\mathrm{GW}$, and habitats were the most effective at improving water quality, while CC and wetlands made the greatest water quality improvement in lands with multiple existing conservation practices. Spatial optimization resulted in similar cost-environmental benefit tradeoff curves for each watershed, with the greatest possible water quality improvement being a reduction in total pollutant loads by approximately $60 \%$, with nitrogen reduced by $20-30 \%$, phosphorus by $70 \%$, and sediment by $80-90 \%$.
\end{abstract}

(KEY TERMS: optimization; best management practices; agricultural conservation practices; nutrients; Soil and Water Assessment Tool; watershed management.)

Kalcic, Margaret M., Jane Frankenberger, and Indrajeet Chaubey, 2015. Spatial Optimization of Six Conservation Practices Using SWAT in Tile-Drained Agricultural Watersheds. Journal of the American Water Resources Association (JAWRA) 51(4): 956-972. DOI: 10.1111/1752-1688.12338

\section{INTRODUCTION}

Scientists and watershed managers have long advocated a targeting approach to placement of conservation practices to protect surface waters from agricultural pollution, and researchers continue to refine these targeting approaches (e.g., Hession and Shanholtz, 1988; Crumpton, 2001; Heathwaite et al., 2005; Diebel et al., 2008, 2009; Tuppad et al., 2010). Although widely recommended, targeting approaches have rarely been used to allocate conservation funds in the United States (U.S.).

Targeting of conservation has taken many forms, from geospatial approaches to watershed-scale modeling. Generally the goal of individual targeting efforts falls under one of three categories. First, targeting "hotspots" in the watershed involves seeking to find and protect with conservation the spatial locations responsible for the greatest pollution. A second approach is targeting certain conservation practices to locations where a practice is most suitable. Finally,

\footnotetext{
${ }^{1}$ Paper No. JAWRA-13-0263-P of the Journal of the American Water Resources Association (JAWRA). Received December 6, 2013; accepted August 15, 2014. (C) 2015 American Water Resources Association. Discussions are open until six months from issue publication.

${ }^{2}$ Research Fellow (Kalcic), University of Michigan Water Center, 625 E. Liberty, Suite 300, Ann Arbor, Michigan 48104; Professor (Frankenberger), Agricultural and Biological Engineering; and Professor and Department Head (Chaubey), Earth, Atmospheric, and Planetary Sciences, Purdue University, West Lafayette, Indiana 47907 (E-Mail/Kalcic: mkalcic@umich.edu).
} 
watershed modeling allows for targeting locations that have the greatest potential for or efficiency of water quality improvement. Past targeting studies that used each of these approaches are summarized below.

Many believe that water quality pollution is derived from hotspots in the landscape due to a combination of vulnerable lands and poor farm management (Nowak et al., 2006). Targeting these locations with conservation can protect farmland and water quality. Targeting hotspots is not a new idea; Hession and Shanholtz (1988) presented a targeting method for limiting soil erosion from critical source areas using a GIS methodology. More recently, Tuppad et al. (2010) employed a watershed modeling approach where subbasins with the greatest sediment yield were prioritized for reduced tillage, filter strips (FS), and terraces in a Kansas watershed. Targeting conservation to hotspots is not limited to water quality pollution, but rather can extend to other conservation goals such as wildlife habitat protection for species diversity (Brown et al., 2009).

Many targeting efforts have started with a conservation practice of interest and searched for the most suitable locations for that practice. A good example of this approach is locating suitable sites for wetland creation. Numerous wetland targeting studies have been conducted to strategically place constructed wetlands for greatest nitrate removal from agricultural tile drainage (Crumpton, 2001; Tomer et al., 2003, 2013b; Kalcic et al., 2012). All have been geospatial approaches, using data layers such as topography, land use, and locations of drainage ditches to select suitable wetland locations.

Watershed modeling combined with spatial optimization is more complex than the other targeting methods, but potentially capable of achieving the most optimal conservation scenario for a watershed. Veith et al. (2004) show that spatial optimization can achieve lower cost scenarios than targeting. Bekele and Nicklow (2005) performed a spatial optimization of land use and tillage to minimize nitrogen, phosphorus, sediment, and cost. Their optimization framework loosely coupled the Soil and Water Assessment Tool (SWAT) (Arnold et al., 1998) with Strength Pareto Evolutionary Algorithm 2 (SPEA2) (Zitzler et al., 2001), and had 12 land management options including no-tillage (NT) of corn and soybeans, along with perennial crops of sorghum, hay, pasture, and fescue grass. Many researchers (Maringanti et al., 2009, 2011; Rodriguez et al., 2011) have since employed spatial optimization of conservation practices through the coupling of SWAT and the nondominated sorting genetic algorithm (NSGA-II) (Deb et al., 2002).

\section{Spatial Optimization Using the SWAT}

Interest has grown in spatial optimization of numerous conservation practices using genetic algorithms and SWAT (e.g., Bekele and Nicklow, 2005; Maringanti et al., 2011) as greater computing resources make such computationally intensive approaches more feasible. SWAT is a watershed model commonly used to simulate the impact of land use and land management changes on water quantity and water quality (Arnold et al., 1998). SWAT inputs include soil types, land use data, elevation data, climate data, and land management data. Within the model setup, a large watershed is delineated from elevation data and optional locations of rivers and streams. Several smaller subwatersheds are delineated within the large watershed, and the smallest spatial units are the hydrologic response units (HRUs) within subwatersheds, which generally have uniform soil type and land management.

Maringanti et al. (2009) further developed an optimization method to identify locations for conservation in agricultural lands. They optimized the locations of FS, NT, and nutrient management in an Arkansas watershed, minimizing cost as well as water quality impairment through three separate indices for phosphorus, nitrogen, and sediment export from each HRU. Maringanti et al. (2011) applied a similar method to an Indiana watershed, and combined the three water quality indices into one aggregate pollutant value. Rodriguez et al. (2011) optimized the locations of pasture grazing practices, poultry litter management, and FS in an Arkansas watershed. These three studies used a best management practice (BMP) tool to sever the dynamic linkage to the SWAT model. The BMP tool uses SWAT runs to summarize BMP effectiveness and cost by land use in a database format. While this tool vastly decreases the computational time necessary for the optimization, it may not lead to the most optimal solution at the watershed scale. A dynamic linkage between SWAT and the genetic algorithm would ensure the fitness of each individual conservation placement scenario is calculated using SWAT.

\section{Building Upon Current Approaches}

Our approach builds upon these past studies in four primary ways: (1) several conservation practices are considered here that were not included in these works, such as cover crops (CC) and constructed wetlands; (2) the dynamic linkage with the SWAT model is retained so that cost and water quality are calculated directly from SWAT outputs, rather than BMP tool estimates; (3) the HRUs are defined by field 
boundaries, which are more meaningful boundaries for conservation programs; (4) SWAT's new drainage routine more accurately models the tile drainage common in Corn Belt watersheds. These distinctions are detailed in the following sections.

Model Representation of Conservation Practices. SWAT is capable of simulating a wide range of conservation practices commonly used in agricultural lands, and methods for doing so are described in Arabi et al. (2008) and Waidler et al. (2009). Simulating these practices frequently requires adjusting numerous parameters related to the design of a practice or its potential to impact hydrology and water quality. However, parameterization of wetlands and cereal rye $\mathrm{CC}$, two common practices for water quality improvement in Indiana, were not discussed. This study is the first we are aware of to include wetlands and cereal rye in a spatial optimization using SWAT.

Estimating Costs of Conservation. Costs of conservation are generally economic costs incurred by the farmer for choosing to use conservation on his land. These include the costs of practice installation or initiation, annual maintenance, the opportunity cost of lost agricultural land for structural practices, and cost of foregone yield for field management practices. While costs can be calculated in several ways, many spatial optimization approaches have estimated the costs of conservation from Natural Resources Conservation Service (NRCS) estimates and practice standards (e.g., Maringanti et al., 2009; Rodriguez et al., 2011). Costs are generally considered over some practice lifetime, such as 5, 10, or 20 years.

Defining the HRU by Field Boundaries. In the SWAT model, an HRU is a set of discrete land areas with common land use, soil type, and slope within a subwatershed. This method of HRU definition limits the applicability of the SWAT model to optimization of conservation practices that are to be placed within farm fields. Indeed, most conservation efforts occur at the farm scale, as a result of a farmer's and/or landowner's decision. If optimization results spread across multiple farm fields, multiple farmers/landowners would need to agree to implement the practices in order to achieve an optimal result. In our work HRUs are instead defined by field boundaries (Kalcic et al., 2014). The primary advantage of our approach is that conservation practices are simulated to be implemented at the field scale, by a single farmer, and results can be viewed at the field scale for clarity in displaying results to farmers and landowners as well. No other studies were found that considered field boundaries in the placement of conservation practices for spatial optimization.
Accurately Modeling Tile-Drained Lands. Subsurface drainage is common in the poorly drained, fairly flat farm fields that are characteristic of west-central Indiana and much of the U.S. Corn Belt, and should be included in watershed models and optimization on those lands. Tiles permit drainage waters rich in nitrate to flow rapidly toward drainage ditches and streams, short-circuiting the biologically active upper soil layers, and contributing considerable loads of nitrate to surface waters (Hickey and Doran, 2004; Gentry et al., 2009). Heavily tile-drained watersheds drastically alter hydrology and nutrient export from agricultural lands.

It is critical to simulate tile drainage properly in watersheds when estimating conservation practice effectiveness. Many conservation practices will perform differently in tile-drained watersheds. Tile flows will bypass filtering through vegetated buffer strips and grassed waterways (GW), resulting in reduced nitrate removal efficiencies. Wetlands are recommended for placement in tile-drained watersheds as one of the few practices capable of treating nitrate from tile drains. Even the performance of NT and CC may change as tiles allow for greater infiltration and reduced surface runoff.

Moriasi et al. (2012, 2013) developed a physically based method for simulating tile drainage in the SWAT model. While simulating tile drainage had been possible in SWAT previously using what we refer to as the "original tile drainage routine" (Du et al., 2005), this "new" method uses the Hooghoudt and Kirkham tile drain equations that have been used in the DRAINMOD model. Although expected to be an improvement over the previous tile drain simulation method, little research has been conducted to evaluate the new method, and no other optimization studies were found to consider it.

\section{Goal of the Work}

Our work serves to extend spatial optimization with the SWAT model by including conservation practices relevant to tile-drained agricultural lands, defining HRUs by field boundaries, and simultaneously optimizing the placement of many conservation practices to determine the most efficient conservation scenarios for two case study watersheds.

\section{MATERIALS AND METHODS}

\section{Study Watersheds}

Two watersheds in west-central Indiana, the Little Pine $\left(56 \mathrm{~km}^{2}\right)$ and Little Wea Creek $\left(45 \mathrm{~km}^{2}\right)$ water- 
sheds, were used for this demonstration (Figure 1). Land use is primarily agricultural in both watersheds, with $87-92 \%$ of the land maintained in corn and soybean row crops, $5 \%$ in other agricultural crops, and $3-7 \%$ is forested or low density urban. Soils in both watersheds require artificial drainage for optimal crop production; in Little Pine, 68\% of row crops have soils that are somewhat poorly, poorly, or very poorly drained (majority in the somewhat poorly drained category), while in Little Wea $84 \%$ of row crops have poorly drained soils (majority in the poorly drained category). Both watersheds are flat or gently sloping, with an average slope of $1.2 \%$ for Little Pine and 1.9\% for Little Wea. Only 2\% of Little Pine's lands and $8 \%$ of Little Wea's exceed a $5 \%$ slope.

Model Setup. Tile drainage and HRU definition were both notable deviations from most SWAT studies. The SWAT model was set up using version 622 , with its new tile drainage routine activated. HRUs were defined by field boundaries (Kalcic et al., 2014) so that the optimization would consider each field separately

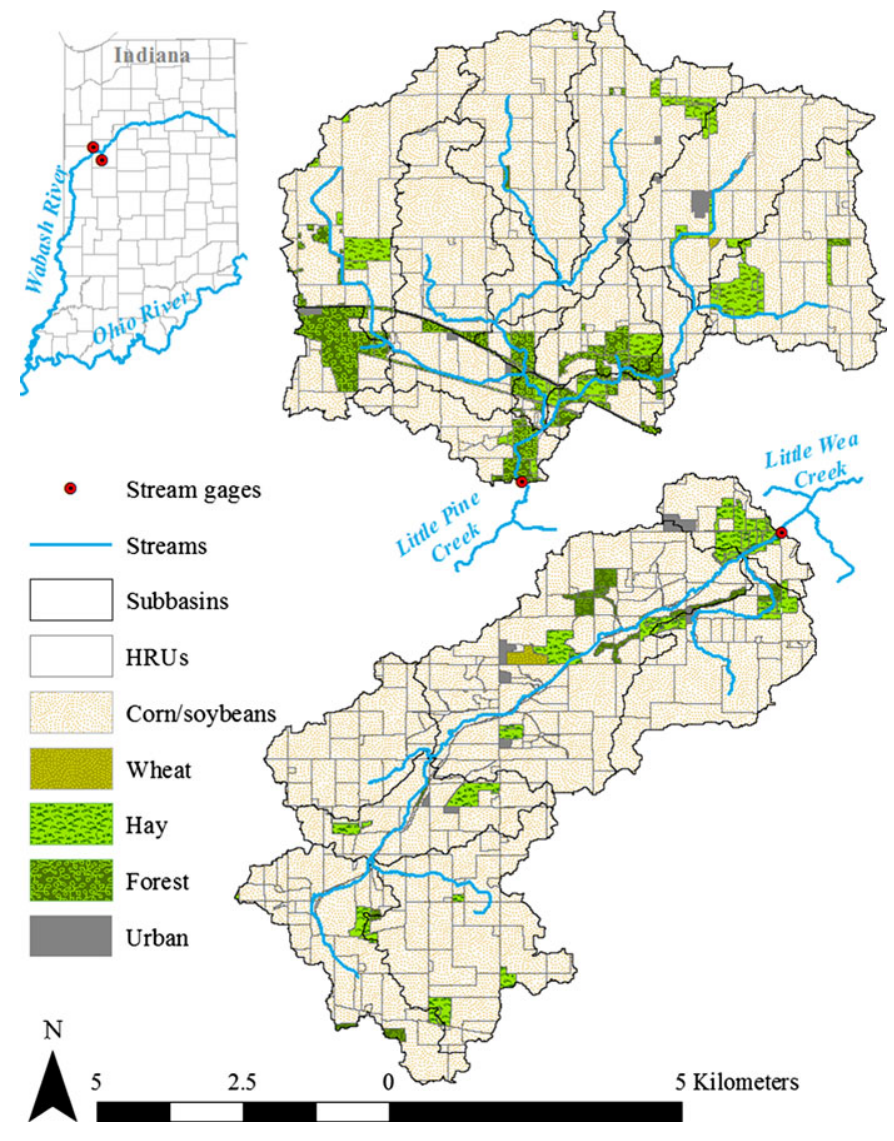

FIGURE 1. Study Watersheds, Little Pine Creek Watershed (top), and Little Wea Creek Watershed (bottom) Are Located in West-Central Indiana. Watersheds are not located as close together as shown. in placing conservation practices in the watershed. Land use and soils were preprocessed in the shape of farm fields, and a single slope class was used for slope definition, so no threshold was used in SWAT HRU definition. Instream water quality modeling, which is based upon the QUAL2E model (Brown and Barnwell, 1987), was turned off for this modeling work, as many others have done, though this had little effect on nutrient and sediment loading.

Inputs to the SWAT model included a $10-\mathrm{m}$ (onethird arc second) resolution digital elevation model (National Elevation Dataset, 2009), National Hydrography Dataset high-resolution streams for burning in the SWAT reach (National Hydrography Dataset, n.d.), daily precipitation and minimum and maximum daily temperatures (National Climate Data Center, n.d.), land use data (National Agricultural Statistics Service Cropland Data Layer, 2009), and soil data (Soil Survey Geographic (SSURGO) Database, 2005). Watershed delineation in the SWAT model resulted in fifteen subwatersheds in the Little Pine Creek watershed and seven in the Little Wea Creek watershed. Dividing HRUs by common land units resulted in 418 HRUs in Little Pine, of which 320 were corn and soybean land use, and 396 HRUs in Little Wea, of which 311 were corn and soybeans.

Model Parameter Changes and Crop Management. Crop management varies spatially based on farm operator and land conditions, but in the absence of field-scale information on crop management assumptions must be made as to a generic crop management scheme in the study area. A management file for agricultural lands planted in corn and soybean was developed in conversation with farmers and local agronomy experts, and is shown in Table 1.

Fertilizer application rates followed Extension recommendations (Vitosh et al., 1995) for the average crop yields for Tippecanoe County, Indiana, during the simulation dates of 2007-2012, which averaged $10.1 \mathrm{t} / \mathrm{ha} / \mathrm{yr}(161 \mathrm{bu} / \mathrm{acre} / \mathrm{yr})$ for corn and $3.3 \mathrm{t} / \mathrm{ha} / \mathrm{yr}$ (49 bu/acre/yr) for soybeans (National Agricultural Statistics Service County Level Data, n.d.). Extension recommendations (Vitosh et al., 1995) for achieving these crop yields resulted in an estimated application rate of $181 \mathrm{~kg} / \mathrm{ha}$ nitrogen and $49 \mathrm{~kg} / \mathrm{ha}$ phosphorus. The majority of nitrogen was assumed to be applied primarily as anhydrous ammonia in the spring prior to planting corn using injection beneath the soil surface. Phosphorus fertilizer was applied broadcast and subsequently incorporated into the soil once every two years in the fall after soybean harvest. Common forms of phosphorus fertilizer are DAP (di-ammonium phosphate, 18-46-0), MAP (mono-ammonium phosphate, 11-52-0), or APP (ammonium polyphosphate, 11-37-0), which contain nitrogen meaning that addi- 
Kalcic, Frankenberger, and Chaubey

TABLE 1. Baseline Management and Parameters to Represent Watershed Characteristics.

\begin{tabular}{|c|c|c|c|c|}
\hline Crop & Date & Operation & \multicolumn{2}{|c|}{ Details } \\
\hline Corn & October 10 prior to plant & $\begin{array}{l}\text { Phosphorus and associated nitrogen } \\
\text { application; broadcast and incorporated }\end{array}$ & \multicolumn{2}{|c|}{$\begin{array}{l}49 \mathrm{~kg} \text { P/ha from DAP/MAP/APP } \\
15 \mathrm{~kg} \text { N/ha from DAP/MAP/APP } \\
100 \% \text { applied to top } 10 \mathrm{~mm} \text { of soil }\end{array}$} \\
\hline Corn & October 14 prior to plant & Chisel plow & \multicolumn{2}{|c|}{$30 \%$ mixing to a depth of $150 \mathrm{~mm}$} \\
\hline Corn & April 15 & Offset disk plow & \multicolumn{2}{|c|}{$60 \%$ mixing to $100 \mathrm{~mm}$ depth } \\
\hline Corn & April 22 & Injected nitrogen application & \multicolumn{2}{|c|}{$\begin{array}{l}181 \mathrm{~kg} \text { N/ha from anhydrous ammonia } \\
20 \% \text { applied to top } 10 \mathrm{~mm} \text { of soil }\end{array}$} \\
\hline Corn & May 6 & Planted & \multirow{4}{*}{\multicolumn{2}{|c|}{$5 \%$ mixing to a depth of $25 \mathrm{~mm}$}} \\
\hline Corn & October 14 & Harvested & & \\
\hline Soybean & May 24 & No-tillage planting & & \\
\hline Soybean & October 7 & Harvested & & \\
\hline \multicolumn{5}{|c|}{$\begin{array}{l}\text { Tile Drainage Parameters for All "Poorly Drained" Corn and Soybean HRUs (SSURGO Drainage Class "Very Poorly Drained," } \\
\text { "Poorly Drained," and "Somewhat Poorly Drained") }\end{array}$} \\
\hline \multicolumn{2}{|c|}{ Parameter } & \multicolumn{2}{|l|}{ Explanation } & Value \\
\hline \multicolumn{2}{|c|}{ DDRAIN (mm) } & \multicolumn{2}{|l|}{ Drain depth; depth from soil surface to tile drains } & 1,000 \\
\hline \multicolumn{2}{|c|}{ GDRAIN (h) } & \multicolumn{2}{|c|}{ Drain tile lag time; time for water to travel from soil through drain to the reach } & 24 \\
\hline \multicolumn{2}{|c|}{ DEP_IMP for tile-drained (mm) } & \multicolumn{2}{|c|}{ Depth to impervious soil layer } & 1,200 \\
\hline \multicolumn{2}{|c|}{ ITDRN (flag) } & \multicolumn{2}{|l|}{ Flag to use new drainage routine } & 1 \\
\hline \multicolumn{2}{|c|}{ RE_BSN (mm) } & \multicolumn{2}{|l|}{ Effective drain radius } & 20 \\
\hline \multicolumn{2}{|c|}{ SDRAIN_BSN (mm) } & \multicolumn{2}{|l|}{ Distance between two tiles } & 20,000 \\
\hline \multicolumn{2}{|c|}{ DRAIN_CO_BSN (mm/day) } & \multicolumn{2}{|l|}{ Daily drainage coefficient } & 20 \\
\hline \multicolumn{2}{|c|}{ PC_BSN $(\mathrm{mm} / \mathrm{h})$} & \multicolumn{2}{|l|}{ Pump capacity } & 0 \\
\hline \multicolumn{2}{|c|}{ LATKSATF_BSN } & \multicolumn{2}{|c|}{ Multiplication factor: ratio of lateral $k_{\text {sat }}$ to $k_{\text {sat }}$ from soils database } & 4 \\
\hline \multicolumn{2}{|c|}{ CN2 for tile-drained (value) } & \multicolumn{2}{|c|}{ Initial runoff curve number } & $-20 \%$ \\
\hline
\end{tabular}

Other Parameters Altered to Better Represent Watershed Characteristics

\begin{tabular}{lll}
\hline Parameter & \multicolumn{1}{c}{ Explanation } & Value \\
\hline DEP_IMP for undrained (mm) & Depth to impervious soil layer & 3,000 \\
SURLAG (days) & Surface runoff lag coefficient & 0.5 \\
\hline
\end{tabular}

Note: HRUs, hydrologic response units; DAP, di-ammonium phosphate; MAP, mono-ammonium phosphate; APP, ammonium polyphosphate; SSURGO, Soil Survey Geographic.

tional nitrogen was applied in the fall during phosphorus application.

Model Validation. After setting up the model using local input information model parameters were not calibrated because of the short period of record of available measured data, which would not allow separate calibration and validation periods. We used measured data to evaluate the fit of the model's estimate of streamflow and water quality. Streamflow data were obtained from the U.S. Geological Survey (USGS, 2012) for two gaging stations, Little Pine Creek near Montmorenci, Indiana (USGS 033356786) and Little Wea Creek at South Raub, Indiana (USGS 03335673). Weekly concentrations of nitrate, total phosphorus (TP), and sediment were also gathered at the gaging stations for a three-year period in 2009-2012 (Haas et al., 2014a, b, c). Model simulation began with a three-year warm-up period 2004-2006, followed by six years simulation 2007-2012, chosen to cover 2009-
2012, the period for which measured water flow and quality data were available (Haas et al., 2014a, b, c).

Hydrology was tested using standard statistics for model fit, the correlation coefficient $\left(R^{2}\right)$ and the Nash-Sutcliffe coefficient $\left(E_{\mathrm{NS}}\right)$ :

$$
\begin{aligned}
& R^{2}=\left[\frac{\sum_{i=1}^{n}\left(O_{i}-\bar{O}\right)\left(P_{i}-\bar{P}\right)}{\sqrt{\sum_{i=1}^{n}\left(O_{i}-\bar{O}\right)^{2} \sum_{i=1}^{n}\left(P_{i}-\bar{P}\right)^{2}}}\right]^{2} \\
& E_{\mathrm{NS}}=1-\frac{\sum_{i=1}^{n}\left(O_{i}-P_{i}\right)^{2}}{\sum_{i=1}^{n}\left(O_{i}-\bar{O}\right)^{2}}
\end{aligned}
$$

In both equations, $O_{i}$ is the observed value on a given day (month for nitrate), $P_{i}$ is the value predicted by SWAT on a given day (month for nitrate), $\bar{O}$ is the average observed value, $\bar{P}$ is the average predicted value, and $n$ is the number of days over which these 
values are compared. For both $R^{2}$ and $E_{\mathrm{NS}}$, a value of 1 represents a perfect fit, and acceptable ranges for these objective functions are $R^{2}$ greater than 0.6 , and $E_{\mathrm{NS}}$ greater than 0.50 (Engel et al., 2007). An annual depth of flow was also used to determine how much of the flow is simulated by the model.

Nitrate, TP, and sediment concentrations were available on a near-weekly basis for the three-year period of May 2009-2012, totaling 149-153 data points for each analyte. Measured concentrations were converted to loads using observed daily flows, and simulated concentrations and loads were derived from SWAT's output.rch and output.hru output files. Daily mean loads and standard deviations were calculated at each watershed outlet, as well as monthly $R^{2}$ and $E_{\mathrm{NS}}$ values. Instream water quality modeling was turned on for a test, which showed that it made little difference in daily loads, possibly because of the small size of the watersheds and short length of reaches.

\section{Implementing Conservation Practices in SWAT}

Conservation practices were implemented in the SWAT model based on existing guidance (Arabi et al., 2008; Waidler et al., 2009). All conservation practice parameters mentioned below are defined and described in the SWAT model documentation (Neitsch et al., 2009) as well as the Conservation Practice Modeling Guide (Waidler et al., 2009).

Continuous NT. Continuous NT was implemented in an HRU by removing the chisel plow and disk plow before corn tillage operations and reducing curve number by two points (Arabi et al., 2008). The SWAT default NT operation has 5\% mixing to a $25 \mathrm{~mm}$ depth at planting. Corn was NT planted on May 6, and soybean management was unchanged.

Cover Crops. Cover crops were modeled as cereal rye, a recommended CC for this region with parameters available in the SWAT crop database. Cereal rye was planted on October 15 after harvest of both corn and soybean, and killed on April 15 prior to planting corn or soybeans in the spring.

Filter Strips. Filter strips were installed at the start of the warm-up period for the SWAT model runs by setting the following in the .ops file: MGT_OP $=4$ for FS, FILTER_I $=1$ to flag on FS, FILTER_RATIO $=40$ to achieve $2.5 \%$ of field area, FILTER_CON $=0.5$ assuming $50 \%$ of the HRU drains to the most concentrated $10 \%$ of the FS, and FILTER_CH $=0$ to indicate that none of the concentrated flow is fully channelized such that it would bypass filtering effects of the FS.
Grassed Waterways. Grassed waterways were installed at the start of the warm-up period. Parameters that were altered in .ops and .mgt files included MGT_OP $=7$ to simulate GW in the HRU, GWATI $=1$ to flag on GW simulation, and GWATW = 10 to set the average width to $10 \mathrm{~m}$.

Wetlands (W). In the SWAT model, headwater wetlands are placed at the subwatershed scale, where all those in a subwatershed are lumped into one wetland area, volume, and fraction of subwatershed's overland flows that are intercepted. However, the spatial location of a wetland is within one or more HRUs. Unlike the other practices, which can likely be implemented in almost any cropped field, wetlands may be limited in where they can be placed throughout a watershed. For instance, they should be sized according to their upland contributing areas, and a crop field must be large enough to support a wetland of that size. Topography to some extent dictates locations where they can be placed. Also, they should ideally intercept significant flows, so that they remain inundated throughout the year, to support wetland vegetation as well as maximize nutrient removal.

The method for placing wetlands in the watersheds loosely followed that of Kalcic et al. (2012). Potential wetland outlets were identified using spatial layers of flow accumulation (created during SWAT model setup), locations of open streams (National Hydrography Dataset, n.d.), HRU polygons (created during SWAT setup), land use data (National Agricultural Statistics Service Cropland Data Layer, 2009), and orthophotography to further confirm what was learned from the other layers (Indiana Framework Data, 2015). Potential outlets satisfied the following criteria: (1) they had large contributing areas (roughly $0.2 \mathrm{~km}^{2}$ or greater, which is a tenth of the criterion used by Kalcic et al., 2012), determined by location along a major flow accumulation pathway in the subwatershed; (2) they did not intercept an open waterway; (3) wetlands would be located on cropland; (4) wetlands would be sized at $1 \%$ of their contributing area; (5) surrounding buffers constituted an additional $3 \%$ of the contributing area.

To estimate the volume of each wetland, they along with surrounding buffers were assumed to be bowl-shaped. Wetlands were shaped as partial spheres, with one meter depth and radius calculated from a circular surface area with area $1 \%$ of the upland contributing area. Surrounding buffers were assumed to be partial cones, with the smaller radius equivalent to that of the wetland, depth of $1.2 \mathrm{~m}$, and larger radius calculated from a circle with area $4 \%$ of the upland contributing area.

Wetland creation was implemented in SWAT using the .pnd files for each subwatershed where at least 
one was placed (Waidler et al., 2009). WET_FR, the fraction of a subwatershed's area that drains into wetlands within that subwatershed, was calculated as the wetland contributing area divided by the subwatershed area for each unique combination of wetlands in a subwatershed. WET_NSA, the normal surface area of wetlands in a subwatershed, was the sum of all wetland surface areas placed in a given subwatershed. WET_NVOL, the volume of a wetland filled to the normal level, was equal to the sum of the volume of all wetlands placed in a subwatershed. When wetlands are filled to maximum volumes, the wetland surface area, WET_MXSA, and volume, WET_MXVOL, were equal to the sum of wetland and buffer surface areas and volumes, respectively.

The normal concentration of sediments in the wetland, WET_NSED, was left at its default value. Wetland hydraulic conductivity determines how much seepage takes place in the wetland. Hydraulic conductivities of all the soils in the watersheds exceeded $2.6 \mathrm{~mm} / \mathrm{h}$, despite the presence of extensive hydric soils, so this value was used as an upper bound for wetland conductivity, WET_K, and a final value of $2.0 \mathrm{~mm} / \mathrm{h}$ was chosen. Phosphorus settling rates, PSETLW, were not changed from default values of $10 \mathrm{~m} / \mathrm{yr}$. Nitrogen settling rates, NSETLW, however, were altered to $39 \mathrm{~m} / \mathrm{yr}$, based on data analysis from a local wetland located within the Little Pine watershed (McCahon, 2010). Wetland nitrate removal was previously found to compare fairly well to many Midwestern wetlands and was the range of predictions from a model developed by Crumpton et al. (2006) and used by others (Kalcic et al., 2012; Tomer et al., 2013a) that relates nitrate reductions to annual hydraulic loading rates.

Habitats (H). Wildlife habitats were modeled identically to FS, though they are assumed to be tall grass prairie establishments located strategically to intercept concentrated overland flows.

\section{Objective Functions: Cost and Water Quality}

Cost of conservation and associated water quality improvement were used to compare conservation practice scenarios against a baseline scenario and as objective functions for the optimization. The baseline scenario had the model parameter changes and cropland management described above, but included no additional conservation practices because we had access to only a portion of existing conservation practice data in the two watersheds, which if used might have biased the optimization results.
Cost of Conservation. Conservation practice costs were estimated using cost data for FY2012 Indiana Conservation Practices from the USDA NRCS Field Office Technical Guide for the state of Indiana. Conservation practice costs were calculated as a sum of one-time costs, i.e., installation, annual costs, such as maintenance, and foregone income due to yield losses, as follows:

$$
\begin{aligned}
\operatorname{Cost}\left(\frac{\$}{y}\right)= & \frac{\text { Onetime costs }(\$)}{10 y}+\text { Annual costs }\left(\frac{\$}{y}\right) \\
& + \text { Foregone income }\left(\frac{\$}{y}\right)
\end{aligned}
$$

Cost of foregone yield also utilized an estimate of corn (\$232/tonne) and soybean (\$442/tonne) grain price from Index Mundi commodity prices (http:// www.indexmundi.com) averaged over the five year period 2008-2012. Average grain prices have risen rapidly since 2007 , and therefore, the cost of foregone yield, while estimated from the most recent data, will greatly overestimate the cost of conservation prior to 2007. Costs from the Field Office Technical Guide and final costs used for each practice are summarized in Table 2.

Water Quality Improvement. Three water quality indicators are particularly relevant to the intensive agricultural land use in this region, as well as the water quality goals for the Wabash River basin: nitrogen, phosphorus, and sediment. Total nitrogen (TN), TP, and sediment (Sed) loads can be calculated using SWAT outputs at the HRU, subwatershed, and basin scale. Because SWAT's instream water quality modeling was not used, and basin-level pollutant values closely matched HRU-level outputs, a Water Quality Index was calculated at the watershed outlet.

The Water Quality Index was calculated as average, normalized water quality improvement over the baseline scenario at the watershed outlet. Water quality was calculated at the watershed outlet for TN, TP, and Sed as a normalized value by dividing by the pollutant load in the baseline simulation, which had no conservation practices, over a period of six years (2007-2012). Each water quality constituent was given a weighting factor, $W$, where the sum of all weights equals 1 . These three weighted, normalized values create the water quality index as follows:

$$
\begin{aligned}
& \text { WaterQualityIndex }= \\
& \qquad W_{\mathrm{TN}} \frac{\mathrm{TN}}{\mathrm{TN}_{\text {baseline }}}+W_{\mathrm{TP}} \frac{\mathrm{TP}}{\mathrm{TP}_{\text {baseline }}}+W_{\text {Sed }} \frac{\text { Sed }}{\text { Sed }_{\text {baseline }}}
\end{aligned}
$$

The index ranges from 0 , indicating complete pollutant removal in the watershed, to 1 , indicating no 
TABLE 2. Estimation of Costs Using the Field Office Technical Guide Itemized Costs for Conservation Practices, Displayed as One-Time and Annual Costs over a 10-Year Period.

\begin{tabular}{|c|c|c|c|c|c|c|c|}
\hline Category of Costs & $\begin{array}{l}\text { Time-Scale } \\
\text { of Costs }\end{array}$ & $\begin{array}{l}\text { No-Tillage } \\
\$ / \text { ha }\end{array}$ & $\begin{array}{c}\text { Cover Crops } \\
\$ / \text { ha }\end{array}$ & $\begin{array}{c}\text { Filter Strips } \\
\$ / \text { ha }\end{array}$ & $\begin{array}{c}\text { Grassed Waterways } \\
\$ / \text { ha }\end{array}$ & $\begin{array}{l}\text { Wetlands } \\
\$ / \text { ha }\end{array}$ & $\begin{array}{c}\text { Habitats } \\
\quad \$ / \text { ha }\end{array}$ \\
\hline \multirow[t]{2}{*}{ Materials } & One-time & $\$ 0$ & $\$ 0$ & $\$ 356$ & $\$ 1,790$ & $\$ 1,048$ & $\$ 1,167$ \\
\hline & Annual & $\$ 0$ & $\$ 109$ & $\$ 0$ & $\$ 0$ & $\$ 0$ & $\$ 0$ \\
\hline \multirow{2}{*}{$\begin{array}{l}\text { Equipment, } \\
\text { installation and labor }\end{array}$} & One-time & $\$ 271$ & $\$ 0$ & $\$ 59$ & $\$ 8,080$ & $\$ 5,977$ & $\$ 35$ \\
\hline & Annual & $\$ 12$ & $\$ 54$ & $\$ 0$ & $\$ 0$ & $\$ 0$ & $\$ 0$ \\
\hline $\begin{array}{l}\text { Operation, maintenance } \\
\text { and replacement }\end{array}$ & Annual & $\$ \theta$ & $\$ \theta$ & $\$ 12$ & $\$ 197$ & $\$ \theta$ & $\$ \theta$ \\
\hline $\begin{array}{l}\text { Acquisition of technical } \\
\text { knowledge }\end{array}$ & Annual & $\$ 7$ & $\$ \theta$ & $\$ \theta$ & $\$ \theta$ & $\$ \theta$ & $\$ \theta$ \\
\hline Foregone income & Annual & \multicolumn{6}{|c|}{ Yield reduction was predicted by the SWAT model } \\
\hline Risk & One-time & $\$ \theta$ & $\$ \theta$ & $\$ 21$ & $\$ \theta$ & $\$ \theta$ & $\$ 60$ \\
\hline \multirow[t]{2}{*}{ Total } & One-time & $\$ 271$ & $\$ 0$ & $\$ 415$ & $\$ 9,870$ & $\$ 7,024$ & $\$ 1,203$ \\
\hline & Annual & $\$ 12$ & $\$ 163$ & $\$ 0$ & $\$ 0$ & $\$ 0$ & $\$ 0$ \\
\hline
\end{tabular}

Notes: SWAT, Soil and Water Assessment Tool.

* Costs that are crossed out were not considered to be calculated consistently across all practices and therefore were not used in the total costs for the optimization.

water quality benefit from conservation. A value greater than 1 would mean increased water quality impairment. The baseline scenario would have a Water Quality Index of 1, but other scenarios could have values of 1 if they had no net improvement of $\mathrm{TN}, \mathrm{TP}$, and Sed. In fact, many combinations of TN, $\mathrm{TP}$, and Sed could lead to similar Index values. We chose to weight each constituent equally, so that $W_{\mathrm{TN}}=W_{\mathrm{TP}}=W_{\mathrm{Sed}}=\frac{1}{3}$, but a different weighting approach could be used to focus the optimization more on one or two of the factors.

\section{Conservation Practice Scenarios}

Conservation practice scenarios were used to evaluate the effectiveness of conservation practices in the watershed, as well as initialize the first generation of the optimization. Many scenarios were considered, and two sets of scenarios were chosen: one-at-a-time addition and one-at-a-time removal of conservation practices. One-at-a-time addition was chosen to rate the effectiveness of an individual conservation practice in the absence of any other conservation efforts. The best-performing single practice should dominate optimization solutions seeking for small water quality improvements at low cost, and inclusion of these scenarios in the initial population will allow the optimization to converge more quickly on this "tail" of possible solutions. One-at-a-time removal was chosen to identify the nutrient-reduction redundancy of a practice with other conservation practices. If one-at-a-time removal indicates that a given practice is responsible for significant nutrient or sediment reduction, even in the presence of all other practices, that practice will likely be present in high-cost and best water quality solutions.

Each scenario for conservation in the watersheds was run by setting all corn and soybean HRUs to one conservation practice scheme and analyzing the output at the scale of every HRU and each basin. Oneat-a-time addition for each conservation practice was compared to a baseline scenario with no conservation in any HRUs. One-at-a-time removal was compared to a complete set of conservation practices in every cropped HRU. All scenarios were compared based on average annual pollutant loads, the Water Quality Index, and cost over the baseline scenario. To test the influence of tile drainage on conservation practice effectiveness, all scenarios were run with the new tile drainage approach, and also with the original tile drainage approach and in the absence of tile drainage.

\section{Genetic Algorithm Optimization Approach}

Spatial optimization of conservation practices utilized a genetic algorithm approach called the nondominated sorting genetic algorithm (NSGA II) (Deb et al., 2002). The genetic algorithm seeks to determine the optimal tradeoff front that minimizes the two objective functions. One-at-a-time addition and removal scenarios were included in the initial population in order to hasten the model convergence on the optimal front. Each generation had 50 individual scenarios, which each had a genetic code of a set of conservation practices implemented in the watershed. All six conservation practices could be placed simultaneously in each corn or soybean HRU, except for wetlands, which were only placed in allowable HRUs as 
presented above. Scenarios that provided a better cost and Water Quality Index than their peers were selected to move to the next generation. Half of these were crossed with each other, and similar to parents creating offspring, a portion of their genetic code was given to the offspring. All individual scenarios then underwent mutation at low rates (0.001 chance of mutation for each HRU). Spatial optimization took place automatically through a code built in MATLAB (The MathWorks Inc., 2012), using parallel computing to reduce the time of running the SWAT model for each individual scenario. To plot final optimal curves, 50 evenly spaced bins were created from highest cost to lowest cost solutions, and individuals with the lowest Water Quality Index in each bin were selected from all generations.

\section{RESULTS AND DISCUSSION}

\section{Watershed Model Validation}

Uncalibrated models have previously been shown to have satisfactory hydrologic prediction (Srinivasan et al., 2010), and this was the case in our work. Both watersheds had fairly good prediction of daily flow at the outlet for 2009-2012 period for which measured data were available, especially considering the model was not calibrated. Daily flows for Little Pine's had an $R^{2}$ of 0.63 and $E_{\mathrm{NS}}$ of 0.63 , and for Little Wea had an $R^{2}$ of 0.60 and $E_{\mathrm{NS}}$ of 0.56 . Annual flow depth was fairly close for both watersheds; Little Pine had $0.39 \mathrm{~m} / \mathrm{yr}$ observed flow and $0.42 \mathrm{~m} / \mathrm{yr}$ simulated, while Little Wea's annual flows were $0.45 \mathrm{~m} / \mathrm{yr}$ observed and $0.37 \mathrm{~m} / \mathrm{yr}$ simulated. Tile drainage accounted for $41 \%$ of annual flow in Little Pine and $55 \%$ of annual flow in Little Wea.

Average daily nitrate concentrations were within a reasonable range, though somewhat elevated in Little Wea and underpredicted in Little Pine (Table 3). Model outputs showed that nitrate made up the majority of TN in both model setups; in Little Pine, $95 \%$ of TN comes in the form of nitrate, while $88 \%$ of $\mathrm{TN}$ in nitrate in Little Wea. Organic nitrogen made up the remaining nitrogen loads. While most nitrogen is transported in the nitrate form, tile drainage serves as the conduit for the majority of nitrate: $91 \%$ in Little Pine and 94\% in Little Wea. Therefore, simulated nitrate loads are sensitive to drainage parameters and the portion of flow traveling through tiles. Standard deviations reveal that variation was greater in the simulation than the measured samples (Table 3), as the model tended to overestimate peak nitrate loading. Gentry et al. (2009) demonstrated
TABLE 3. Comparison of Simulated and Observed Water Quality to Assess Soil and Water Assessment Tool Model Performance in Little Pine and Little Wea Watersheds, Shown with Daily Mean $(\mu)$ and Standard Deviation $(\sigma)$.

\begin{tabular}{|c|c|c|c|c|}
\hline & \multicolumn{2}{|c|}{ Little Pine Watershed } & \multicolumn{2}{|c|}{ Little Wea Watershed } \\
\hline & $\begin{array}{l}\text { Simulated } \\
(n=1,279)\end{array}$ & $\begin{array}{c}\text { Observed } \\
(n=153-155)\end{array}$ & $\begin{array}{l}\text { Simulated } \\
(n=1,279)\end{array}$ & $\begin{array}{c}\text { Observed } \\
(n=149-153)\end{array}$ \\
\hline \multicolumn{5}{|c|}{ Nitrate concentrations (mg/L) } \\
\hline$\mu$ & 3.2 & 6.6 & 4.5 & 4.5 \\
\hline$\sigma$ & 5.1 & 4.0 & 7.3 & 2.7 \\
\hline \multicolumn{5}{|c|}{ Nitrate loading (kg/day) } \\
\hline$\mu$ & 520 & 560 & 570 & 370 \\
\hline$\sigma$ & 1,800 & 1,000 & 2,000 & 780 \\
\hline \multicolumn{5}{|c|}{ Phosphorus concentrations (mg/L) } \\
\hline$\mu$ & 0.20 & 0.14 & 0.55 & 0.05 \\
\hline$\sigma$ & 0.11 & 0.13 & 0.44 & 0.11 \\
\hline \multicolumn{5}{|c|}{ Phosphorus loading (kg/day) } \\
\hline$\mu$ & 11 & 13 & 22 & 10 \\
\hline$\sigma$ & 16 & 44 & 40 & 52 \\
\hline \multicolumn{5}{|c|}{ Sediment concentrations $(\mathrm{mg} / \mathrm{L})$} \\
\hline$\mu$ & 37 & 22 & 150 & 14 \\
\hline$\sigma$ & 29 & 33 & 190 & 39 \\
\hline \multicolumn{5}{|c|}{ Sediment loading (kg/day) } \\
\hline$\mu$ & 2,700 & 4,200 & 7,600 & 5,100 \\
\hline$\sigma$ & 5,400 & 22,000 & 20,000 & 33,000 \\
\hline
\end{tabular}

that nitrate concentrations from heavily tile-drained watersheds tended to decrease in peak flow events through dilution with overland flow, and our measured data suggests the same, but at times our simulation had elevated nitrate concentrations during high flow events. We suspect the discrepancy may be driven by the mineralization of nitrogen into nitrate in SWAT.

Phosphorus and sediment loading were generally reasonable (Table 3), although a higher than anticipated proportion of simulated sediment and phosphorus was delivered in lower flows. This meant average concentrations were elevated for both watersheds compared to measured data, especially sediment concentrations in Little Wea. Sediment loads in Little Pine were underpredicted because the model missed a couple of high peak flows, likely due to errors in the climate data. Both phosphorus and Sed loads were considerably decreased when tile drainage was added to the model (data not shown). The latest versions of SWAT permit mineral phosphorus transport through tile drains, and simulated mineral phosphorus loading was especially high in the Little Pine watershed, where it contributed to $49 \%$ of TP during the 2009-2012 period. Soluble phosphorus loading made up $15 \%$ of TP in Little Wea for that same three-year period.

Water quality evaluation for monthly average nitrate, TP, and Sed loads demonstrated a reasonable fit according to $R^{2}$, but the overprediction of phospho- 
rus and sediment yielded poor fits for $E_{\mathrm{NS}}$ (data not shown). Monthly $R^{2}$ values were generally $0.4-0.6$, but $E_{\mathrm{NS}}$ values were at or below zero for all but nitrate in Little Pine $\left(E_{\mathrm{NS}}=0.46\right)$. The relatively poor monthly prediction of nutrient loading was due to excessive soil erosion and high sediment concentrations during low flow, as well as a difficulty in capturing peak flow events with the new tile drainage routine.

Finally, accurate simulation of crop yields is critical to ensure applied nutrients are being used by the plant, as well as to ensure reasonable estimates of foregone yield in the cost calculation of spatial optimization. Actual crop yields were estimated using data for Tippecanoe County, Indiana, which includes the majority of both watersheds, during the simulation period 2007-2012 (National Agricultural Statistics Service County Level Data, n.d.). Measured crop yields were estimated to be $10.1 \mathrm{t} / \mathrm{ha} / \mathrm{yr}$ for corn and $3.3 \mathrm{t} / \mathrm{ha} / \mathrm{yr}$ for soybeans during the simulation period. These compare fairly well to simulated crop yields, as the two watersheds had average corn yields of 10.3$10.4 \mathrm{t} / \mathrm{ha} / \mathrm{yr}$ and soybean yields of 2.8-2.9 t/ha/yr. Corn yields were more variable than soybean yields, and more sensitive to the parameter values used for tile drainage and the curve number reduction. The underprediction of soybean yields may influence nutrient uptake and losses.

\section{Conservation Practice Representation}

This section outlines the representation of two conservation practices - wetlands and CC - that are not frequently modeled with SWAT.

Potential Wetland Locations. We found 22 potential wetland locations in the Little Pine watershed, averaging 16.5 ha including the surrounding buffer area, and 25 potential wetland locations averaging 5.2 ha in size in the Little Wea watershed. Wetlands in Little Pine intercepted flows from $66 \%$ of the watershed, including five wetlands nested within other wetland drainage areas, while Little Wea's wetlands would intercept $58 \%$ of the watershed and contained only one wetland nested within another wetland's drainage area.

Wetland representation in SWAT is limited in a number of ways. First, SWAT does not provide a framework for using wetlands at a scale smaller than the subwatershed. A wetland with drainage area of one-third of a subwatershed would not actually intercept that third, but rather filter one-third of the overland flows coming from all HRUs in the entire subwatershed. This limitation is inherent when using SWAT to model wetlands, unless all possible wet- lands are located at subwatershed outlets. Second, wetlands implemented through the .pnd routine are not modeled to intercept subsurface flows, so tile drainage does not pass through them. This is a considerable limitation in tile-drained watersheds, where headwater wetlands are recommended to treat the elevated levels of nitrate leaching through these drains (Dinnes et al., 2002; Crumpton et al., 2006), and should be addressed in future SWAT development. Third, SWAT's nutrient removal algorithms for wetlands are fairly simplistic, and rely on annual nitrogen and phosphorus settling rates, which were difficult to estimate as they might fluctuate a great deal from one wetland to another (McCahon, 2010).

Cover Crop Growth. Cover crop establishment is a critical factor in their nutrient-cycling performance, so it was important to confirm that SWATsimulated crop growth was within a reasonable range. SWAT annual outputs at the HRU-level lump all crop biomass within a year into one value, so CC biomass could not be separated from the corn or soybean crop that followed. Therefore, cereal rye biomass was assumed to make up the difference between total crop biomass in the CC scenario and the baseline scenario, which is reasonable considering the simulated corn and soybean yields were essentially unaffected by the presence of a CC (data not shown). Simulated growth of cereal rye indicated fairly good establishment most years, with the average crop field attaining a biomass of $1.5 \mathrm{t} / \mathrm{ha}$ by the time it was killed in the spring. Although no measured data on CC biomass were available for these watersheds, experiments in Illinois found average annual biomass of 2.2-6.1 t/ha (Ruffo et al., 2004), which are likely a little higher than expected in the simulation, because the crop was killed at least two weeks later than assumed in our simulations. The rye did not grow much in the winter months, but grew rapidly in March and April, and is sensitive to the precise kill time in April. Maximum crop growth exceeded 4 t/ha in some HRUs in spring of 2012, when temperatures were much warmer than usual.

\section{Conservation Practice Scenarios}

Scenarios where only one or all but one conservation practice was applied in every corn and soybean HRU allowed for simple comparison of conservation practices as shown in Tables 4 and 5 for Little Wea and Little Pine. These tables include information on the average cost and Water Quality Index for each scenario, along with loading of each water quality constituent. Two additional nutrient forms commonly exported through tile drainage - nitrate and mineral 
TABLE 4. Scenario Results for Six Years of Simulation in the Little Pine Watershed. One-at-a-time addition scenarios indicate placement of zero or one conservation practice through all corn and soybean hydrologic response units, while one-at-a-time removal scenarios indicate placement of all or all but one conservation practice. Cost is the mean $(\mu)$ annual cost of conservation in cropland per hectare of watershed, and nutrient and sediment export average annual $(\mu)$ export at the watershed outlet per hectare of watershed.

\begin{tabular}{|c|c|c|c|c|c|c|c|}
\hline Scenario & $\begin{array}{c}\text { Cost of Scenario } \\
\$ / \mathbf{h a} / \mathbf{y r} \\
\mu\end{array}$ & $\begin{array}{c}\text { TN Export } \\
\mathrm{kg} \mathrm{N} / \mathrm{ha} / \mathrm{yr} \\
\mu\end{array}$ & $\begin{array}{c}\mathrm{NO}_{3} \text { Export } \\
\mathrm{kg} \mathrm{N} / \mathrm{ha} / \mathrm{yr} \\
\mu\end{array}$ & $\begin{array}{c}\text { TP Export } \\
\text { kg P/ha/yr } \\
\mu\end{array}$ & $\begin{array}{c}\text { Mineral P } \\
\text { Export } \\
\mathrm{kg} \mathrm{P} / \mathrm{ha} / \mathrm{yr} \\
\mu\end{array}$ & $\begin{array}{c}\text { Sed Export } \\
\text { t/ha/yr } \\
\mu\end{array}$ & $\begin{array}{c}\text { Water } \\
\text { Quality } \\
\text { Index }\end{array}$ \\
\hline No conservation (None) & $\$ 0$ & 32.48 & 30.78 & 0.82 & 0.22 & 0.19 & 1.00 \\
\hline Habitats (H) & $\$ 42$ & 31.80 & 30.42 & 0.66 & 0.19 & 0.13 & 0.83 \\
\hline Wetlands (W) & $\$ 68$ & 30.94 & 29.88 & 0.51 & 0.16 & 0.08 & 0.66 \\
\hline Grassed waterways (GW) & $\$ 52$ & 32.06 & 30.71 & 0.68 & 0.21 & 0.13 & 0.84 \\
\hline Filter strips (FS) & $\$ 41$ & 31.80 & 30.42 & 0.66 & 0.19 & 0.13 & 0.83 \\
\hline Cover crops (CC) & $\$ 116$ & 24.40 & 23.58 & 0.49 & 0.22 & 0.09 & 0.61 \\
\hline No-tillage (NT) & $\$ 57$ & 32.75 & 31.12 & 1.36 & 0.49 & 0.16 & 1.18 \\
\hline All except no-tillage (- NT) & $\$ 320$ & 23.20 & 22.78 & 0.28 & 0.15 & 0.03 & 0.40 \\
\hline All except cover crops (- CC) & $\$ 258$ & 30.94 & 30.14 & 0.72 & 0.34 & 0.05 & 0.70 \\
\hline All except filter strips (- FS) & $\$ 329$ & 23.36 & 22.97 & 0.34 & 0.19 & 0.02 & 0.42 \\
\hline $\begin{array}{l}\text { All except grassed waterways } \\
\text { (- GW) }\end{array}$ & $\$ 318$ & 23.37 & 22.97 & 0.34 & 0.19 & 0.02 & 0.42 \\
\hline All except wetlands (- W) & $\$ 302$ & 24.54 & 23.91 & 0.57 & 0.31 & 0.05 & 0.58 \\
\hline All except habitats $(-\mathrm{H})$ & $\$ 327$ & 23.36 & 22.97 & 0.34 & 0.19 & 0.02 & 0.42 \\
\hline All conservation practices (All) & $\$ 370$ & 23.55 & 23.16 & 0.37 & 0.22 & 0.02 & 0.43 \\
\hline
\end{tabular}

TABLE 5. Scenario Results for Six Years of Simulation in the Little Wea Watershed. Cost is the mean $(\mu)$ annual cost of conservation in cropland per hectare of watershed, and nutrient and sediment export average annual $(\mu)$ export at the watershed outlet per hectare of watershed.

\begin{tabular}{|c|c|c|c|c|c|c|c|}
\hline Scenario & $\begin{array}{c}\text { Cost of Scenario } \\
\$ / \mathbf{h a} / \mathbf{y r} \\
\mu\end{array}$ & $\begin{array}{c}\text { TN Export } \\
\text { kg N/ha/yr } \\
\mu\end{array}$ & $\begin{array}{c}\mathrm{NO}_{3} \text { Export } \\
\mathrm{kg} \mathrm{N} / \mathrm{ha} / \mathrm{yr} \\
\mu\end{array}$ & $\begin{array}{c}\text { TP Export } \\
\text { kg P/ha/yr } \\
\mu\end{array}$ & $\begin{array}{c}\text { Mineral P } \\
\text { Export } \\
\mathrm{kg} \text { P/ha/yr } \\
\mu\end{array}$ & $\begin{array}{c}\text { Sed Export } \\
\text { t/ha/yr } \\
\mu\end{array}$ & $\begin{array}{c}\text { Water } \\
\text { Quality } \\
\text { Index }\end{array}$ \\
\hline No conservation (None) & $\$ 0$ & 45.63 & 40.39 & 1.89 & 0.13 & 0.61 & 1.00 \\
\hline Habitats (H) & $\$ 45$ & 44.00 & 40.12 & 1.38 & 0.11 & 0.32 & 0.74 \\
\hline Wetlands (W) & $\$ 70$ & 44.27 & 39.84 & 1.58 & 0.11 & 0.49 & 0.87 \\
\hline Grassed waterways (GW) & $\$ 61$ & 44.03 & 40.34 & 1.36 & 0.13 & 0.32 & 0.74 \\
\hline Filter strips (FS) & $\$ 43$ & 44.00 & 40.12 & 1.38 & 0.11 & 0.32 & 0.74 \\
\hline Cover crops (CC) & $\$ 109$ & 33.43 & 31.01 & 0.90 & 0.13 & 0.27 & 0.55 \\
\hline No-tillage (NT) & $\$ 70$ & 45.14 & 40.53 & 2.66 & 0.26 & 0.53 & 1.09 \\
\hline All except no-tillage (- NT) & $\$ 329$ & 31.93 & 30.51 & 0.54 & 0.10 & 0.11 & 0.39 \\
\hline All except cover crops (- CC) & $\$ 287$ & 42.65 & 39.93 & 1.58 & 0.21 & 0.22 & 0.71 \\
\hline All except filter strips (- FS) & $\$ 339$ & 31.93 & 30.65 & 0.63 & 0.12 & 0.09 & 0.39 \\
\hline $\begin{array}{l}\text { All except grassed waterways } \\
(- \text { GW) }\end{array}$ & $\$ 321$ & 32.02 & 30.64 & 0.65 & 0.12 & 0.09 & 0.40 \\
\hline All except wetlands (- W) & $\$ 312$ & 32.82 & 31.28 & 0.80 & 0.17 & 0.12 & 0.45 \\
\hline All except habitats $(-\mathrm{H})$ & $\$ 337$ & 31.93 & 30.65 & 0.63 & 0.12 & 0.09 & 0.39 \\
\hline All conservation practices (All) & $\$ 382$ & 32.12 & 30.82 & 0.66 & 0.14 & 0.10 & 0.40 \\
\hline
\end{tabular}

phosphorus - were also included to demonstrate the ability of each conservation practice to intercept or prevent nutrients from passing through tiles.

Our results show aggregated and averaged data for hydrology and water quality. While Tables 4 and 5 present mean loading rates from the watershed, not all constituents had normal distributions around those means. Phosphorus and sediment loading were more readily removed by most practices, but also had strongly skewed distributions (data not shown) where a small number of crop fields were responsible for a disproportionate share of the watershed's soil erosion, a common finding (Nowak et al., 2006). Most of these lands were classified in the SSURGO soils database as highly erodible, and may already have conservation measures in place.

One-at-a-Time Addition and Conservation Practice Effectiveness. The single conservation practice scenarios (Tables 4 and 5) show the impact of each practice on water quality and allow us to evaluate their performance against the literature. 
Filter strips and habitats provided the most costeffective water quality benefit in the watershed, followed by GW, which behaved similarly (Tables 4 and 5). These in-field and edge-of-field practices were simulated to treat $17-27 \%$ of phosphorus in the watershed, but had very low nitrate reduction $(0-1 \%)$ for these edge-of-field practices. Nitrate reduction in FS can be quite high (48-100\%) in the absence of tile drainage, but much reduced when bypassed by tile drains (Dinnes et al., 2002). In Illinois, a field-scale study on vegetated FS revealed that FS may have little nitrogen or phosphorus reduction benefit in tiledrained fields (Bhattarai et al., 2009). In Iowa, a gamagrass strip placed over a tile drain, which is similar to a GW, did not significantly alter tile drainage flows or nitrate loading (Kaspar et al., 2007).

Our wetland scenario was in the lower cost range and somewhat effective at improving water quality, but because of the model's limitation they do not intercept tile drainage and so their potential to remove nitrogen is underestimated. Wetland nitrogen removal rates of $2-4 \%$ of nitrate and $5-7 \%$ of $\mathrm{TN}$ were not in the range of monitoring data from Ohio, Illinois, and Iowa wetlands, which treated 35,37 , and $52 \%$ of inflow nitrate respectively (Kovacic et al., 2000; Mitsch et al., 2005; Helmers et al., 2009). Our simulated phosphorus removal rates of $28-57 \%$ may be overestimated considering wetlands may not be a significant source or sink of phosphorus (Kovacic et al., 2000).

Our estimation of CC showed greater expense than other practices, but also greater nitrate and phosphorus removal than most practices. Cereal rye simulation reduced watershed scale loading of nitrate by $23 \%$ and phosphorus by $40-52 \%$, and lowered flow through tile drains by $4-5 \%$. In the tile-drained Midwest, monitoring from field plots in Minnesota and Iowa found cereal rye reduced nitrate loading from tile drainage from $13 \%$, when rye was applied only after corn in a corn-soybean rotation (Strock et al., 2004 ), to $48-61 \%$, when applied every year after harvest of row crops (Kaspar et al., 2007, 2012).

Finally, NT did little to reduce simulated nitrogen and phosphorus export from crop fields, as nitrate still passed through tile drainage and phosphorus was left on the soil surface where it was more available to runoff compared to the baseline scenario, where tillage incorporated phosphorus into the soil within days of fertilization. Previous modeling and plot- and field-scale monitoring efforts show that NT can increase nutrient losses in tile-drained conditions over conventional tillage. A long-term field study on continuous corn in Minnesota showed NT increased tile flow by $12 \%$ and reduced nitrate losses by only $5 \%$ compared to conventional tillage (Randall and Iragavarapu, 1995). In a field-scale experiment in
Southwestern Ontario, NT resulted in $45 \%$ more drainage water volume and $26 \%$ greater nitrate losses compared with conventional tillage (Tan et al., 1998). Simulated rainfall experiments on corn and soybean crops under various tillage regimes resulted in significantly greater level of dissolved phosphorus from NT than other treatments (McIsaac et al., 1995).

One-at-a-Time Removal. When five of the six practices were applied to every corn and soybean $\mathrm{HRU}$, the impact of removing the practice from a suite of all practices was evident, referred to as the one-at-a-time removal scenarios (Tables 4 and 5). If removal of one practice resulted in worsening water quality, that practice was influential in improving water quality even under high conservation conditions. FS and GW were no longer influential, while $\mathrm{CC}$ and wetlands were capable of removing nutrients and especially sediments that the other practices could not intercept. FS and GW intercepted pollutants in a similar way at the edge-of-field, while CC were on the field and wetlands received runoff from all overland flow in their contributing areas and were therefore uniquely placed to intercept pollutants. Therefore, CC and wetlands may be recommended in regions where more conservation is already taking place. In fact, using the current conservation practice representation in these particular case study watersheds, CC were essential in the suite of practices to reduce all water quality pollutants. $\mathrm{CC}$ were the most effective practice at reducing nitrogen loading, likely because they can process nutrients in the field before nitrate passed into the tile and beyond the reach of GW, FS, and habitats to remediate. Wetlands, when placed most efficiently, could be highly effective as well.

Influence of Tile Drainage. To analyze the importance of tile drainage in this approach we ran the same scenarios with the original tile drainage routine and also with no tile drainage. The original drainage routine provided similar results with slightly less flow through tiles, which corresponded with slightly lower nitrogen loading and greater phosphorus and sediment loading. The Water Quality Index was unchanged for each practice combination, and costs were similar, except for $\mathrm{CC}$ which were much less expensive $(\$ 24 / \mathrm{ha} / \mathrm{yr}$ for Little Wea and $\$ 58 / \mathrm{ha} / \mathrm{yr}$ for Little Pine) due to a greater influence on improving corn yields. Corn yield decreased by 10$15 \%$ in all scenarios lacking CC using the original tile drainage routine and by only $3-6 \%$ when $\mathrm{CC}$ were applied.

Nutrient and sediment loading in the undrained no conservation scenarios showed striking shifts to 
lower nitrogen loading (TN reduced by $58-66 \%$ and nitrate by $80-85 \%)$ and much higher sediment and phosphorus loading (130\% increase in TP, 50-100\% increase in mineral phosphorus, and 100-140\% increase in sediment). When conservation practices were applied in the absence of drainage, all practices were more capable of reducing normalized TN loading, as a greater portion of it was delivered in the organic form through overland flow. Practices treated greater phosphorus and Sed loads, but loading was so high they could not treat a greater portion of these constituents, and so the Water Quality Indices decreased by up to $25 \%$ for one-at-a-time removal scenarios. These results show that not only is loading of nutrients and sediments in the model quite sensitive to the presence of tile drains, but conservation practice performance is affected as well. In intensively drained parts of the Corn Belt we suggest that for hydrology and water quality prediction it is critical to incorporate appropriate tile drainage such that a considerable portion of flow passes through tiles.

Wetland performance improved considerably in the absence of tile drainage as wetlands were able to intercept all flow from their contributing areas. Under both tile drainage routines, wetlands scenarios only removed an average 5-8\% of TN losses in their contributing areas. Without subsurface drainage, they treated roughly twice the nitrogen load, and because nitrogen loading was lower overall this amounted to $24-39 \%$ of TN and $28-38 \%$ of all nitrate exported in their contributing areas, bringing the estimate in range of wetlands monitored in Ohio, Illinois, and Iowa (Kovacic et al., 2000; Mitsch et al., 2005; Crumpton et al., 2006; Helmers et al., 2009). Phosphorus and sediment treatment in wetlands was not nearly as affected by tile drainage because these contaminants were primarily lost through overland flow. Clearly this work underestimates the relative effectiveness of wetlands compared to other practices as the current wetland routine does not intercept tiledrained flows.

\section{Spatial Optimization of Conservation Scenarios}

Spatial optimization converged upon a Pareto optimal front (Deb, 2001) within roughly 100 generations of 50 individuals, which was surprising as most optimization studies run for thousands of generations (Maringanti et al., 2009, 2011; Rodriguez et al., 2011), although Bekele and Nicklow (2005) stopped simulations after 50 generations. After 1,000 generations, evenly binned optimal solutions were selected and plotted alongside the initial conservation scenarios, which were present in the first generation, as shown in Figure 2.
The optimal curve is expected to be truly near-optimal, but this cannot be proven without running optimizations using other algorithms and comparing them. Following the curves in Figure 2 from lowest cost solutions to highest cost solutions, it is clear that water quality can be improved considerably, although the rate of water quality improvement steepens dramatically on the left tail of the optimal curve. In both watersheds, fairly low-cost solutions are capable of removing up to approximately $50 \%$ of pollutants, while cost increases more rapidly up to a pollutant removal of $60 \%$. The presence of a water quality improvement threshold is expected for pollutant removal, where the first portion of pollutants can be removed readily but complete removal may be costly or impossible as the hardest to reach pollutants persist.

Initial conservation practice scenarios provide a sense of which practices are present along the optimal curves (Figure 2). It appears that FS, habitats, and GW dominate in the right hand tail of lower cost and smaller water quality improvement, while CC account for much of the steeper, left tail of the curve. This inference is not proven by Figure 2, but is supported by additional inspection not detailed here. It is notable that the optimal curve lies quite near to these initial scenarios, suggesting that a simple recommendation for one practice in an entire watershed may be able to achieve a near-optimal solution. If no conservation was present in these watersheds, one could simply recommend that all farms incorporate FS or GW, and achieve a $15-25 \%$ improvement in water quality. Conversely, if FS and GW are already prevalent in these lands, one might suggest $\mathrm{CC}$ or a few targeted wetlands to achieve further water quality improvement.

\section{Sensitivity and Limitations of the} Approach. The outcome of this optimization approach could be quite sensitive to the objective functions chosen. Cost of conservation (Equation 3 and Table 2), the first objective function, depends on assumptions made in determining cost of conservation practices. For instance, CC other than cereal rye may have greater or lesser seed costs. NT costs assumed a one-time transition cost for the procurement of new equipment divided over an average farm size, and yet once purchased by a farm the cost of converting additional lands to NT should be lower. Cost of foregone yield depends on the current grain prices, which are subject to monthly and annual fluctuations, and also on SWAT's estimation of crop yields. Crop yields were fairly steady throughout the conservation scenarios, although they were influenced by NT and a preceding CC. Annual corn yields were slightly reduced (1-2\%) by NT, while soybeans were 

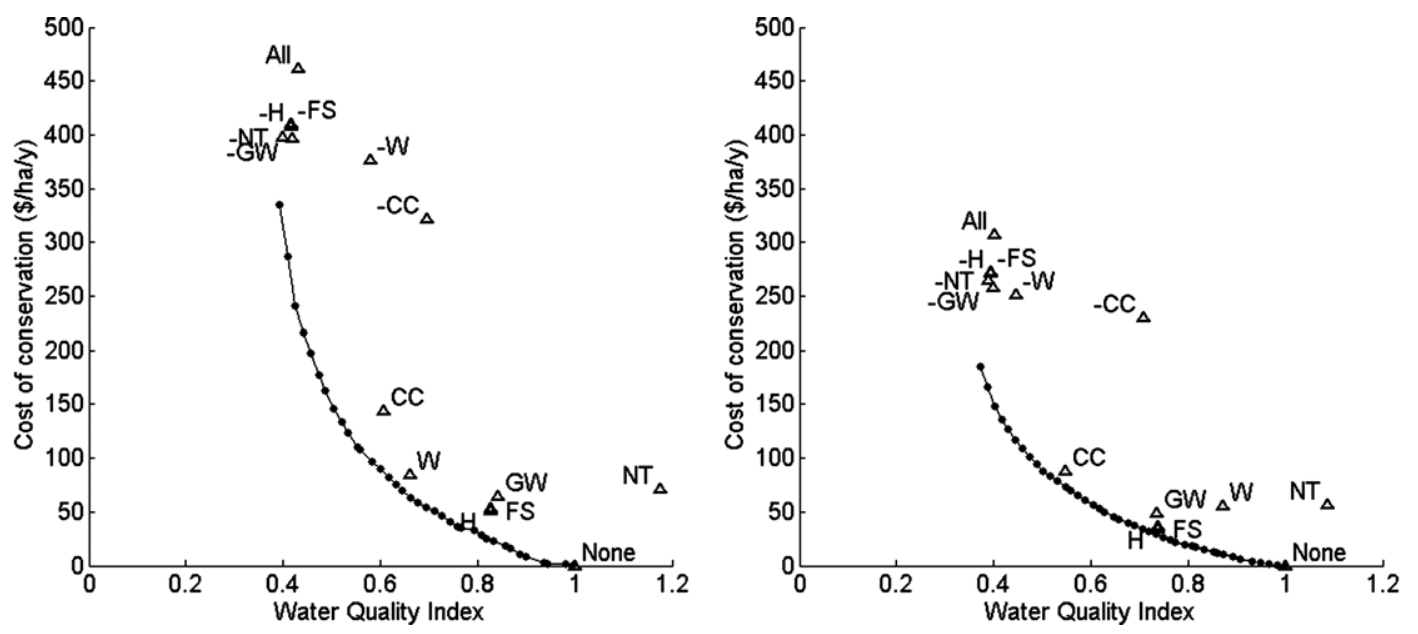

One-at-a-time addition scenarios
None: No conservation
NT: No-tillage
CC: Cover crops
FS: Filter strips
GW: Grassed waterways
W: Wetlands
H: Habitats
One-at-a-time removal scenarios
All: All conservation practices
- NT: All except no-tillage
- CC: All except cover crops
- FS: All except filter strips
- GW: All except grassed waterways
- W: All except wetlands
- H: All except habitats

FIGURE 2. Optimization Results for Conservation Practice Scenarios, Plotted Alongside Initial One-at-a-Time Addition and One-at-a-Time Removal Conservation Scenarios, after 1,000 Generations for Conservation in the Little Pine (left) and Little Wea (right) Watersheds.
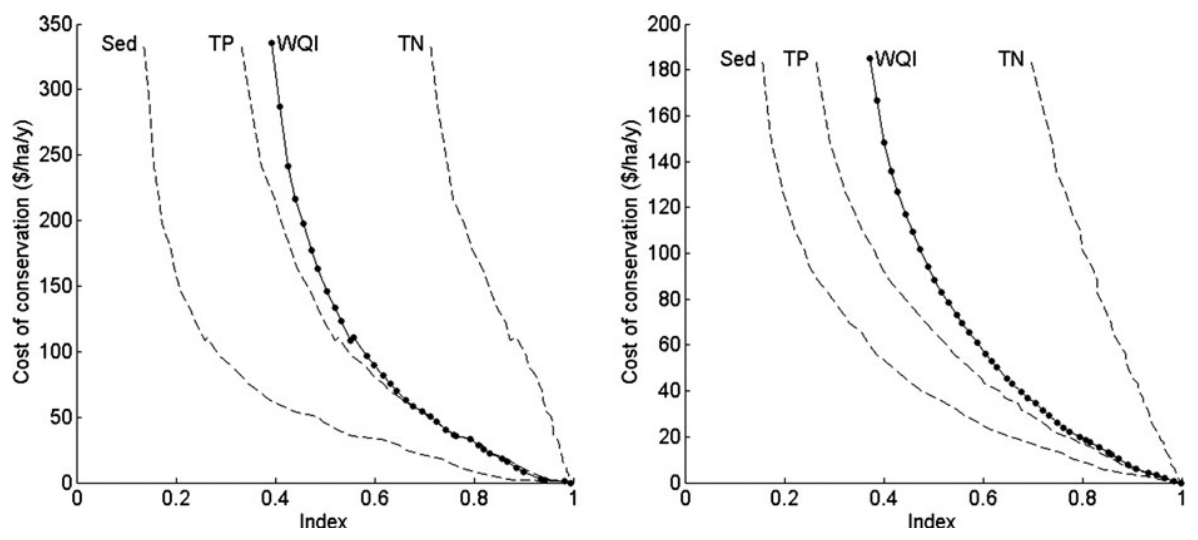

FIGURE 3. Water Quality Index (WQI) Plotted Alongside Each Normalized Water Quality Constituent for Optimal Conservation Scenarios after 1,000 Generations in the Little Pine (left) and Little Wea (right) Watersheds. Despite uniform weighting in Equation (4), the model predicted sediment and phosphorus were more readily reduced than nitrogen in these watersheds.

unaffected. CC, on the other hand, led to a yield boost of $2 \%$ for corn and $0-2 \%$ for soybeans. These yield impacts were consistent when multiple practices were used simultaneously, such that NT and CC counteracted one another. The modest yield reduction in NT can be explained by the reduction in curve number, which may have increased waterlogging in the soil. CC may have increased crop yields somewhat either through drying of the soil during the wet spring or through pulling up nutrients that would have been lost over the winter and providing them to the subsequent row crop.

The optimization approach may have also been sensitive to the formulation of the second objective function - the Water Quality Index (Equation 4) and particularly our decision to combine three water quality constituents into one. While the Water Quality Index reached 0.4 in the scenarios with the highest implementation of conservation practices, its three constituents - nitrogen, phosphorus, and sediment - were not all reduced by the same percentage (Figure 3). Because sediment and phosphorus were more readily intercepted by conservation practices, the optimization was able to find lower cost solutions for a particular value of the Water Quality Index by reducing these pollutants than reducing nitrogen. If one constituent was more critical than the others, it could be weighted more heavily in the Index to achieve results more in line with that water quality goal. Alternatively, the Index could be formulated without normalizing to a baseline scenario, or a different baseline could be chosen. The three pollutants all demonstrated decision fronts that improved with more costly scenarios, and this is because the three were correlated with one another (Figure 3). If the three were 
in competition with one another we would expect to see tradeoffs and the decision front may be less smooth.

Many additional factors could contribute to optimality, and we can examine differences in the optimization outcomes by comparing the two simulated watersheds. CC had greater cost in Little Pine than Little Wea, where they provided a larger boost to corn yields. Better performance of wetlands in Little Pine than Little Wea may be an artifact of the wetland locations manually chosen, but demonstrate the importance of choosing suitable sites for wetland creation. Little Wea watershed was able to reach a slightly better water quality improvement than Little Pine, primarily due to its ability to reduce phosphorus loading more readily through conservation. Not all watersheds would behave similarly to these, and even between these two proximate watersheds we have evidence of different conservation practice effectiveness.

Ultimately the adoption of optimal conservation practices would depend on decisions made by farmers and landowners about private lands. The decision maker installing the practice may have existing practices not known by the model, or preferences for future conservation projects. Some practices may be easier for a decision maker to adopt than others. For instance, GW and FS require cooperation from both farmers and landowners. CC may not require cooperation from a landowner, and could be more suitable for farms where landowners will not agree to take land out of production. Wetlands, though costly and large projects, are capable of intercepting pollutants from sources far upstream and may not require cooperation with as many landowners to make a large impact.

\section{CONCLUSIONS}

This study extended SWAT modeling through representation of six conservation practices, and the spatial optimization approach through definition of HRUs by field boundaries and simultaneous simulation of many conservation practices. FS, GW, and strategically placed wildlife habitats would achieve the most cost-effective reduction in all three water quality pollutants on nearly all lands. CC may have greater cost, and were not needed to reduce erosion and phosphorus runoff, yet they provided the greatest nitrate-leaching protection in these flat, extensively tile-drained watersheds. Wetlands were sensitive to location, had reduced efficiency when nested within other wetlands' drainage areas, and may provide quite different results if nutrient and sediment removal parameters were adjusted. Wetland nitrogen removal was considerably underestimated in this approach because the current SWAT routines for ponds and wetlands permits tile drainage flows to bypass wetland treatment. For the most part, NT was ineffective at reducing all three of the water quality pollutants of concern, because it left an untouched soil surface with high concentrations of phosphorus vulnerable to runoff through erosive flows. In the baseline scenario, phosphorus was incorporated into the soil within days of application, where it was not nearly as accessible to transport in runoff, and so combining NT with banding of phosphorus below the surface may improve phosphorus losses. NT is also known to have long-term soil formation benefits, not considered in this short-term modeling exercise.

Spatial optimization revealed an opportunity to apply lower cost solutions to reduce loading of nitrogen, phosphorus, and sediment by $50 \%$ at the watershed scale. If greater reductions are required, costs may increase exponentially to capture $60 \%$ of pollutants in the watershed. Even greater reductions may not be possible with the current set of conservation practices, particularly due to the lower bound on nitrate removal caused by excessive nitrate flows through subsurface tile drainage. However, formulation of one Water Quality Index equally weighting nitrogen, phosphorus, and sediment reductions encouraged conservation practices capable of intercepting sediment and phosphorus rather than nitrogen. Nitrogen reductions were more difficult to achieve as most leaching came as nitrate through tile drainage. In order to effectively treat these nitrate losses, additional conservation practices such as drainage water management, wetlands that intercept tile drainage, or bioreactors may be needed.

While this work demonstrates that a fairly complex, computationally intensive targeting can be achieved, there is also hope that simpler targeting efforts could be near-optimal - even some of the simple initial conservation practice scenarios appeared near the Pareto optimal front, and it is not difficult to imagine simple geospatial targeting by soil type, land use, and slope could be quite effective. Other limitations of our work include the water balance, nutrient, and sediment performance of the uncalibrated SWAT model in the Little Wea Creek watershed, the unknown parameter values for many conservation practices, estimations of cost, and of course the limitations of the current SWAT model in representing conservation practices. There is always an opportunity to improve the representation of these practices through measured data and calibration of practice parameters, such as the wetland pollutant removal 
rates. We hope that simulation of wetlands in SWAT will be improved to include denitrification rates and permit wetlands to intercept tile drainage from their contributing area. This modeling work may also be used quite practically with policy makers, conservation planners, and even farmers or landowners, and such an approach can be used adaptively through interactions with these stakeholders.

\section{ACKNOWLEDGMENTS}

Primary funding for this work came from a USDA NRCS Conservation Innovation Grant. This work was also partially funded by the University of Michigan Graham Sustainability Institute and by the Great Lakes Restoration Initiative (administered by USEPA) through a NOAA-GLERL SOAR project.

\section{LITERATURE CITED}

Arabi, M., J.R. Frankenberger, B.A. Engel, and J.G. Arnold, 2008. Representation of Agricultural Conservation Practices with SWAT. Hydrological Processes 22:3042-3055.

Arnold, J.G., R. Srinivasan, R.S. Muttiah, and J.R. Williams, 1998. Large Area Hydrologic Modeling and Assessment: Part I. Model Development. Journal of the American Water Resources Association 34(1):73-89.

Bekele, E.G. and J.W. Nicklow, 2005. Multiobjective Management of Ecosystem Services by Integrative Watershed Modeling and Evolutionary Algorithms. Water Resources Research 41:W10406, doi: 10.1029/2005WR004090.

Bhattarai, R., P.K. Kalita, and M.K. Patel, 2009. Nutrient Transport through a Vegetative Filter Strip with Subsurface Drainage. Journal of Environmental Management 90:18681876.

Brown, D.J., D.M. Spontak, M.N. Tibbets, A.R. Connolly, and J.T. Baccus, 2009. Enhancing the Farm Bill's Conservation Potential through Land Prioritization. Journal of Wildlife Management 73(4):620-625.

Brown, L.C. and T.O. Barnwell, Jr., 1987. The Enhanced Water Quality Models QUAL2E and QUAL2E-UNCAS Documentation and User Manual. EPA document EPA/600/3-87/007. USEPA, Athens, Georgia.

Crumpton, W.G., 2001. Using Wetlands for Water Quality Improvement in Agricultural Watersheds; the Importance of a Watershed Scale Approach. Water Science and Technology 44 (11-12):559-564.

Crumpton, W.G., G.A. Stenback, B.A. Miller, and M.J. Helmers, 2006. Potential Benefits of Wetland Filters for Tile Drainage Systems: Impact on Nitrate Loads to Mississippi River Subbasins. U.S. Department of Agriculture, Project Report IOW06682. http://www.apfo.usda.gov/Internet/FSA_File/fsa_final_report_ crumpton_rhd.pdf, accessed December 2010.

Deb, K., 2001. Multi-Objective Optimization Using Evolutionary Algorithms. John Wiley \& Sons Inc., New York City, New York, ISBN-13: 978-0470743614.

Deb, K., A. Pratap, S. Agarwal, and T. Meyarivan, 2002. A Fast and Elitist Multiobjective Genetic Algorithm: NSGA-II. IEEE Transactions on Evolutionary Computation 6(2):182-197.

Diebel, M.W., J.T. Maxted, P.J. Nowak, and M.J. Vander Zanden, 2008. Landscape Planning for Agricultural Nonpoint Source Pollution Reduction I: A Geographical Allocation Framework. Environmental Management 42:789-802.
Diebel, M.W., J.T. Maxted, D.M. Robertson, S. Han, and M.J. Vander Zanden, 2009. Landscape Planning for Agricultural Nonpoint Source Pollution Reduction III: Assessing Phosphorus and Sediment Reduction Potential. Environmental Management 43:69-83.

Dinnes, D.L., D.L. Karlen, D.B. Jaynes, T.C. Kaspar, J.L. Hatfield, T.S. Colvin, and C.A. Cambardella, 2002. Nitrogen Management Strategies to Reduce Nitrate Leaching in Tile-Drained Midwestern Soils. Agronomy Journal 94(1):153-171.

Du, B., J.G. Arnold, A. Saleh, and D.B. Jaynes, 2005. Development and Application of SWAT to Landscapes with Tiles and Potholes. Transactions of the ASAE 48(3):1121-1133.

Engel, B., D. Storm, M. White, J. Arnold, and M. Arabi, 2007. A Hydrologic/Water Quality Model Application Protocol. Journal of the American Water Resources Association 43(5):1223-1236.

Gentry, L.E., M.B. David, F.E. Below, T.V. Royer, and G.F. McIsaac, 2009. Nitrogen Mass Balance of a Tile-Drained Agricultural Watershed in East-Central Illinois. Journal of Environmental Quality 38(5):1841-1847.

Haas, M., S. Peel, and R. Turco, 2014a. Biological, Chemical and Flow Characteristics of Five River Sampling Sites in the Wabash River Watershed near Lafayette, Indiana - 2009, doi: 10.4231/R7CC0XM3.

Haas, M., S. Peel, and R. Turco, 2014b. Biological, Chemical and Flow Characteristics of Five River Sampling Sites in the Wabash River Watershed near Lafayette, Indiana - 2010, doi: 10.4231/R77P8W9J.

Haas, M., S. Peel, and R. Turco, 2014c. Biological, Chemical and Flow Characteristics of Five River Sampling Sites in the Wabash River Watershed near Lafayette, Indiana - 2011, doi: 10.4231/R73X84K6.

Heathwaite, A.L., P.F. Quinn, and C.J.M. Hewett, 2005. Modelling and Managing Critical Source Areas of Diffuse Pollution from Agricultural Land Using Flow Connectivity Simulation. Journal of Hydrology 304:446-461.

Helmers, M.J., W.G. Crumpton, P. Lawlor, C.H. Pederson, G.A. Stenback, R. Christianson, and D. Green, 2009. Water and Nutrient Research: In-Field and Offsite Strategies - 2008 Annual Report. Agricultural and Biosystems Engineering Project Reports, Paper 11.

Hession, W.C. and V.O. Shanholtz, 1988. A Geographic Information System for Targeting Nonpoint-Source Agricultural Pollution. Journal of Soil and Water Conservation 43(3):264-266.

Hickey, M.B.C. and B. Doran, 2004. A Review of the Efficiency of Buffer Strips for the Maintenance and Enhancement of Riparian Ecosystems. Water Quality Research Journal of Canada 39(3):311-317.

Indiana Framework Data, 2015. Streaming Geospatial Data, Including Orthophotography. Indiana University. http:// gis.iu.edu/, accessed June 2015.

Kalcic, M., I. Chaubey, and J. Frankenberger, 2015. Defining Soil and Water Assessment Tool (SWAT) Hydrologic Response Units (HRUs) by Field Boundaries. International Journal of Agricultural \& Biological Engineering 8(3), doi: 10.3965/j.ijabe. 20150803.951.

Kalcic, M., I. Chaubey, J. Frankenberger, and E. Kladivko, 2012. A Geospatial Approach to Targeting Constructed Wetlands for Nitrate Removal in Agricultural Watersheds. Applied Engineering in Agriculture 28(3):347-357.

Kaspar, T.C., D.B. Jaynes, T.B. Parkin, and T.B. Moorman, 2007. Rye Cover Crop and Gamagrass Strip Effects on $\mathrm{NO}_{3}$ Concentration and Load in Tile Drainage. Journal of Environmental Quality 36:1503-1511.

Kaspar, T.C., D.B. Jaynes, T.B. Parkin, T.B. Moorman, and J.W. Singer, 2012. Effectiveness of Oat and Rye Cover Crops in Reducing Nitrate Losses in Drainage Water. Agricultural Water Management 110:25-33. 
Kovacic, D.A., M.B. David, L.E. Gentry, K.M. Starks, and R.A. Cooke, 2000. Effectiveness of Constructed Wetlands in Reducing Nitrogen and Phosphorus Export from Agricultural Tile Drainage. Journal of Environmental Quality 29(4):1262-1274.

Maringanti, C., I. Chaubey, M. Arabi, and B. Engel, 2011. Application of a Multi-Objective Optimization Method to Provide Least Cost Alternatives for NPS Pollution Control. Environmental Management 48:448-461.

Maringanti, C., I. Chaubey, and J. Popp, 2009. Development of a Multiobjective Optimization Tool for the Selection and Placement of BMPs for Nonpoint Source Pollution Control. Water Resources Research 45:W06406.

McCahon, M., 2010. Strategically Siting Constructed Wetlands to Target Nitrate Removal in Tile-Drained Agricultural Watersheds. M.S. Thesis, Purdue University, West Lafayette, Indiana.

McIsaac, G.F., J.K. Mitchell, and M.C. Hirschi, 1995. Dissolved Phosphorus Concentrations in Runoff from Simulated Rainfall on Corn and Soybean Tillage Systems. Journal of Soil and Water Conservation 50(4):383-388.

Mitsch, W.J., J.W. Day, L. Zhang, and R.R. Lane, 2005. NitrateNitrogen Retention in Wetlands in the Mississippi River Basin. Ecological Engineering 24:267-278.

Moriasi, D.N., P.H. Gowda, J.G. Arnold, D.J. Mulla, S. Ale, J.L. Steiner, and M.D. Tomer, 2013. Evaluation of the Hooghoudt and Kirkham Tile Drain Equations in the Soil and Water Assessment Tool to Simulate Tile Flow and Nitrate-Nitrogen. Journal of Environmental Quality 42(6):1699-1710.

Moriasi, D.N., C.G. Rossi, J.G. Arnold, and M.D. Tomer, 2012. Evaluating Hydrology of the Soil and Water Assessment Tool (SWAT) with New Tile Drain Equations. Journal of the Soil and Water Conservation 67(6):513-524

National Agricultural Statistics Service County Level Data, n.d. QuickStats 2.0. http://quickstats.nass.usda.gov/, accessed June 2014.

National Agricultural Statistics Service Cropland Data Layer, 2009. http://datagateway.nrcs.usda.gov/, accessed January 2011.

National Climate Data Center, n.d. http://www.ncdc.noaa.gov/cdoweb/, accessed February 2012.

National Elevation Dataset, 2009. One-Third Arc Second Resolution. http://usgs-ybother.srv.mst.edu/HPC/ned13/grid/n36w117/ metadata.htm, accessed May 2015.

National Hydrography Dataset, n.d. High Resolution Streams. http://nhd.usgs.gov/data.html, accessed June 2009.

Neitsch, S.L., J.G. Arnold, J.R. Kiniry, and J.R. Williams, 2009. Soil and Water Assessment Tool Theoretical Documentation Version 2009. Texas Water Resources Institute Technical Report No. 406, College Station, Texas.

Nowak, P., S. Bowen, and P.E. Cabot, 2006. Disproportionality as a Framework for Linking Social and Biophysical Systems. Society \& Natural Resources: An International Journal 19(2):153-173.

Randall, G.W. and T.K. Iragavarapu, 1995. Impact of Long-Term Tillage Systems for Continuous Corn on Nitrate Leaching to Tile Drainage. Journal of Environmental Quality 24(2):360-366.

Rodriguez, H.G., J. Popp, C. Maringanti, and I. Chaubey, 2011. Selection and Placement of Best Management Practices Used to Reduce Water Quality Degradation in Lincoln Lake Watershed. Water Resources Research 47:W01507.

Ruffo, M.L., D.G. Bullock, and G.A. Bollero, 2004. Soybean Yield as Affected by Biomass and Nitrogen Uptake of Cereal Rye in Winter Cover Crop Rotations. Agronomy Journal 96(3):800-805. https://dl.sciencesocieties.org/publications/aj/abstracts/96/3/0800, accesssed June 2015.

Soil Survey Geographic (SSURGO) Database, 2005. Web Soil Survey. http://soildatamart.nrcs.usda.gov/, accessed March 2011.

Srinivasan, R., X. Zhang, and J. Arnold, 2010. SWAT Ungauged: Hydrological Budget and Crop Yield Predictions in the Upper
Mississippi River Basin. Transactions of the American Society of Agricultural and Biological Engineers 53(5):1533-1546.

Strock, J.S., P.M. Porter, and M.P. Russelle, 2004. Cover Cropping to Reduce Nitrate Loss through Subsurface Drainage in the Northern U.S. Corn Belt. Journal of Environmental Quality 33:1010-1016.

Tan, C.S., C.F. Drury, M. Soultani, I.J. van Wesenbeeck, H.Y.F. Ng, J.D. Gaynor, and T.W. Welacky, 1998. Effect of Controlled Drainage and Tillage on Soil Structure and Tile Drainage Nitrate Loss at the Field Scale. Water Science and Technology 38(4-5):103-110.

The MathWorks Inc., 2012. MATLAB Version 7.14.0. The MathWorks Inc., Natick, Massachusetts.

Tomer, M.D., W.G. Crumpton, R.L. Bingner, J.A. Kostel, and D.E. James, 2013a. Estimating Nitrate Load Reductions from Placing Constructed Wetlands in a HUC-12 Watershed Using LiDAR Data. Ecological Engineering 56:69-78.

Tomer, M.D., D.E. James, and T.M. Isenhart, 2003. Optimizing the Placement of Riparian Practices in a Watershed Using Terrain Analysis. Journal of Soil and Water Conservation 58(4):198-206.

Tomer, M.D., S.A. Porter, D.E. James, K.M. Boomer, J.A. Kostel, and E. Mclellan, 2013b. Combining Precision Conservation Technologies into a Flexible Framework to Facilitate Agricultural Watershed Planning. Journal of Soil and Water Conservation 68(5):113A-120A.

Tuppad, P., K.R. Douglas-Mankin, and K.A. McVay, 2010. Strategic Targeting of Cropland Management Using Watershed Modeling. Agricultural Engineering International 12(3):12-24.

USGS (U.S. Geological Survey), 2012. USGS Surface-Water Data for the Nation. http://waterdata.usgs.gov/usa/nwis/sw, accessed January 2012.

Veith, T.L., M.L. Wolfe, and C.D. Heatwole, 2004. Cost-Effective BMP Placement: Optimization Versus Targeting. Transactions of the American Society of Agricultural Engineers 47(5):1585-1594.

Vitosh, M.L., J.W. Johnson, and D.B. Mengel, 1995. Tri-State Fertilizer Recommendations for Corn, Soybeans, Wheat and Alfalfa. Bulletin E-2567. https://www.extension.purdue.edu/extmedia/ AY/AY-9-32.pdf, accessed October 2010.

Waidler, D., M. White, E. Steglich, S. Wang, J. Williams, C.A. Jones, and R. Srinivasan, 2009. Conservation Practice Modeling Guide for SWAT and APEX. http://swat.tamu.edu/media/57882/ Conservation-Practice-Modeling-Guide.pdf, accessed June 2011.

Zitzler, E., M. Laumanns, and L. Thiele, 2001. SPEA2: Improving the Strength Pareto Evolutionary Algorithm. TIK-Report 103, Computer Engineering and Networks Laboratory, Swiss Federal Institute of Technology, Zurich, Switzerland. 